\title{
Fungal Nail Infections: Spectrum of Aetiologic Agents and Pattern of Lesions
}

\author{
Anyimson James, Ogba Ofonime Mark, Abia-Bassey Lydia Nyong \\ Department of Medical Laboratory Science, University of Calabar, Calabar, Nigeria
}

\begin{abstract}
Objective: Worldwide, fungal nail infections have been on the increase, with social, cultural and economic factors contributing to it. Information on the spectrum of fungal nail infection is sparse in Nigeria. This study was carried out to establish the infection rates, aetiology and clinical types of onychomycosis in Calabar.

Methods: Subjects were drawn from manicure and pedicure salons, farming settlements, mechanic workshops and dermatology clinic. A structured questionnaire was administered to participants for demographic data. Nail scrapings and clippings were obtained from subjects under standard aseptic procedure. Samples were pulverized and subjected to microscopy and culture. Standard mycological techniques were used to identify and characterize isolates.

Results: Out of the $32.7 \%$ infection rates in the study, males $33.8 \% \%$ were more infected than females $32.3 \%$ and subjects aged 41-50 years had the highest rate of infections. Candida species were more prevalent $63.6 \%$ than dermatophytic moulds $36.4 \%$. Trichophyton rubrum was the most prevalent $18.2 \%$ dermatophyte. The distribution of pathogenic isolates on fingernails $45.5 \%$ and toenails $42.4 \%$ was statistically significant ( $\chi 2=7.2, p=0.03$ ). Disto-lateral subungual onychomycosis (DLSO) 51(50.5\%) was the most common type of nail lesion but most of the isolates $14(42.4 \%)$ were recovered from TDO. Conclusion: Onychomycosis affected more adults than adolescents of both sexes in our locality. Candida species are becoming prevalent aetiologic agents of these infections, and their importance should not be overlooked in the management of patients. J Microbiol Infect Dis 2016;6(1): 23-27
\end{abstract}

Key words: Onychomycosis, aetiologic agents, lesion types

\section{Fungal Tırnak Enfeksiyonları: Etken Ajanların Dağılımı ve Lezyonların Paternleri}

\section{ÖZET}

Amaç: Fungal tırnak enfeksiyonları sosyal, kültürel ve ekonomik faktörlerin katkısıla dünyanın her yerinde artmaktadır. Nijerya'da fungal tırnak enfeksiyonlarının dağılımı ile ilgili bilgiler yetersizdir. Bu çalışma Kalabar'da onikomikozların enfeksiyon hızlarını, etiyolojilerini ve klinik tiplerini belirlemek için yapıldı.

Yöntemler: Manikür ve pedikür salonlarında, tarım yerleşimlerinde, mekanik atölyelerde ve dermatoloji kliniklerinden örnekler toplandı. Katılımcılara doldurtulan yapılandırılmış bir anketle demografik veriler toplandı. Tırnak kazıntı ve parçaları standart aseptik prosedürle toplandı. Örnekler ezildi ve mikroskobi ve kültür için hazırlandı. İzolatların tanımlanmasında standart mikoloji teknikleri kullanıldı.

Bulgular: Çalışmada enfeksiyon oranı \%32.7 idi (erkeklerde \%33.8, kadınlarda \%32.3) ve bu oran 41-50 yaş arasındakilerde en yüksekti. Candida türleri \%63,6 ile en sık etken idi ve onu \%36,4 ile dermatofitik küfler takip ediyordu. Trichophyton rubrum en sık görülen dermatofit idi \%18,2. El tırnaklarından izole edilen patojenik izolatlar \%45.5 ve ayak tırnaklarından izole edilenler \%42.4 idi $(\chi 2=7,2, p=0,03)$. Disto-lateral subungual onikomikozis (DLSO) 51 hastada $(\% 50,5)$ görüldü ve en sık görülen tırnak lezyon idi fakat en fazla izolat total distrofik onikomikoz (TDO) olgularından izole edildi ( 14 izolat, \%42,4).

Sonuç: Onikomikoz bizim bölgemizde kadın ve erkek erişkinleri adölesandan daha fazla etkilemektedir. Candida türleri bu enfeksiyonlarda en yaygın etken patojen olmaktadır ve bu hastaların tedavisi ihmal edilmemelidir.

Anahtar kelimeler: Onikomikoz, etiyologik ajanlar, lezyon tipleri 


\section{INTRODUCTION}

Onychomycosis are fungal infections of the nails caused by dermatophytes and non-dermatophytes [1]. These nail disorders affect $10 \%$ to $20 \%$ of adults and are quite common. It represents almost half of all nail diseases among adults, especially the elderly $[2,3]$. Dermatophytic fungi of the genus Microsporum, Trichophyton and Epidermophyton are mostly incriminated in onychomycosis [1]. Yeasts (Candida) and non-dermatophytic moulds account for a smaller percentage of the infections. [3] The prevalence of fungal nail infections worldwide ranges from $3-26 \%$, about $3-8 \%$ prevalence has been reported in the United Kingdom [5]. The incidence of new cases of onychomycosis appears to be rising due to the increasing prevalence of immunosuppresion and an ageing population [5]. Onychomycosis are notoriously difficult to treat. Treatment of onychomycosis can be administered topically or orally. A combination of topical and systemic treatment increases the cure rate. Adjunctive surgical measures may also be used $[7,8]$.

Fungal nail infections are divided into four groups depending on their morphological pattern $[9,10]$. These includes; distal lateral subungual onychomycosis (DLSO): The fungi invades the distal or lateral margins of the nail [3]. White Superficial Onychomycosis (WSO) affects the surface of the nail plate with small, white, dotted or powdery patches, which makes the nail rough and weak. Proximal Subungual Onychomycosis (PSO) begins from the proximal location beneath the nail bed. Total dystrophic onychomycosis disfigures the whole nail $[11,12]$. Patients with chronic mucocutaneous candidiasis or immunodepression are predispose to Candida onychomycosis [13].

Related manifestations of nail infection are: Whitish nails associated with onycholysis, red or black nails associated with hematoma and green nails associated with Pseudomonas infections [14]. The risk factors include; male gender, smoking, old age, underlying medical conditions such as diabetes, immunodeficiency, arterial diseases, and genetic factors $[2,15]$.

Worldwide, there is an increase in the incidence of fungal nail infection, with socio- cultural and economic factors contributing to it. This study was designed to determine the prevalence, aetiology and clinical types of fungal nail infections in Calabar, Nigeria.

\section{METHODS}

One hundred and one participants with nail disorder suspected to be fungal infection were recruited into the study after signing an informed consent form. Subjects were drawn from manicure and pedicure salons, farming settlements, mechanic workshops and the dermatology clinic in the University of Calabar Teaching Hospital. Inclusion criteria were the presence of nail lesion resembling fungal infection $[9,13]$. Exclusion criteria included any use of topical or oral antifungal medication within two weeks. A structured questionnaire was administered to all the participants to obtain data on demography (sex, age, marital status) medical history (presence of dystrophic nail, prior treatment, and medication(s) used). Standard mycological techniques were used to characterize the aetiologic agents.

Two consecutive samples were collected from each subject within one week with special consideration to the clinical type of the infection to rule out possible contamination. Nail scrapings, clippings and materials from the nail bed were obtained from subjects using sterile scalpel blade after swabbing the surface with $70 \%$ alcohol. For DLSO, samples were obtained from the nail bed by curettage. Samples were obtained at sites most proximal to the cuticle where the concentration of hyphae is greatest after removing the nail plate. Samples were obtained from the ventral nail plate in proximal subungual onychomychosis after the surface of the nail plate was pared, while in white superficial onychomychosis, specimens were obtained from the nail surface $[2,7]$.

Samples were collected into sterile paper envelopes. Large pieces of nail plate were pulverized prior to microscopy with hammer. Samples were subjected to microscopy using $20 \% \mathrm{KOH}$. The samples were cultured on dermatophyte test medium (DTM) with actidione (LabM Limited, Lancashire, UK) and Sabouraud dextrose agar with chloramphenicol [16]. Plates were incubated at room temperature and at $37^{\circ} \mathrm{C}$, and examined for growth up to 4 weeks.

Pure culture of the isolates was obtained by sub culturing individual isolates onto fresh Sabouraud dextrose agar (SDA) at room temperature $\left(26^{\circ} \mathrm{C}-29^{\circ} \mathrm{C}\right)$ for up to $10-14$ days. In cases of no or slow sporulation, slide culture was carried out [16] Isolates were identified by colonial morphology, microscopy and physiological tests. The physiological tests used in the identification of the dermatophytes 
include: in vitro hair perforation test and urease test [1].

\section{Data Analysis}

Data obtained in the study were analyzed with Epilnfo 2010 statistical software. Interactions between specific categorical clinical variables were tested for significance using the $\chi 2$ test. A p-value of $\leq 0.05$ was considered statistically significant.

\section{RESULTS}

Out of the 101 subjects with clinically suggestive lesions, $32(31.7 \%)$ were females and 69 (68.3\%) were males, the female to male ratio was 1:2.1. Subjects were aged 13-67 years, with a mean age of $36.0 \pm 11.6$ years. Most of the subjects $29(28.7 \%)$ were aged $41-50$ years (Table 1 ).

Table 2 shows the gender distribution of fungal nail infections among subjects. A total of $32.7 \%$ infection rates was recorded in the study, males $23(33.8 \%)$ were more affected than females 10 $(32.3 \%)$, but there was no statistically significant influence of gender on infection rates $(\chi 2=1.7, p=$ $0.8)$.

Candida species were more prevalent 21 (63.6\%) than dermatophytic moulds 12 (36.4\%). Among the dermatophytes, Trichophyton rubrum was the most prevalent $6(18.2 \%)$ while E. flocosum was the least prevalent $2(6.2 \%)$ (Table 3$)$. There was a statistically significant difference between fingernails $15(45.5 \%)$ and toenails $14(42.4 \%)$ infection rates $(\chi 2=7.2, p=0.03$ ). Only $12.1 \%$ of the subjects suffered both finger and toe nail infections (Table 3).

Table 1. Demographic profile of the study subjects.

\begin{tabular}{cccc}
\hline Age group (years) & Female & Male & Total \\
\hline $11-20$ & $3(9.4)$ & $5(7.2)$ & $8(7.9)$ \\
$21-30$ & $15(46.5)$ & $16(23.2)$ & $31(30.7)$ \\
$31-40$ & $5(15.6)$ & $17(24.6)$ & $22(21.8)$ \\
$41-50$ & $8(25.0)$ & $21(30.4)$ & $29(28.7)$ \\
$51-60$ & $1(3.1)$ & $8(11.6)$ & $9(8.9)$ \\
$61-70$ & $0(0.0)$ & $2(2.9)$ & $2(2.0)$ \\
\hline Total & $32(31.7)$ & $69(68.3)$ & 101 \\
\hline
\end{tabular}

Table 2. Distribution of fungal nail infections by gender of subjects.

\begin{tabular}{lcc}
\hline Gender & $\begin{array}{c}\text { No. (\%) with clinically } \\
\text { suggestive lesions }\end{array}$ & No. (\%) positive \\
\hline Female & $31(31.3)$ & $10(30.3)$ \\
Male & $68(68.7)$ & $23(69.7)$ \\
\hline Total & 101 & $33(32.7)$ \\
\hline
\end{tabular}

Figure 1 shows the distribution of fungal isolates by age of subjects. Infection rates peaked at aged 41-50 years, followed by age 21-30 years. Only one isolate was associated with age 61-70 years.

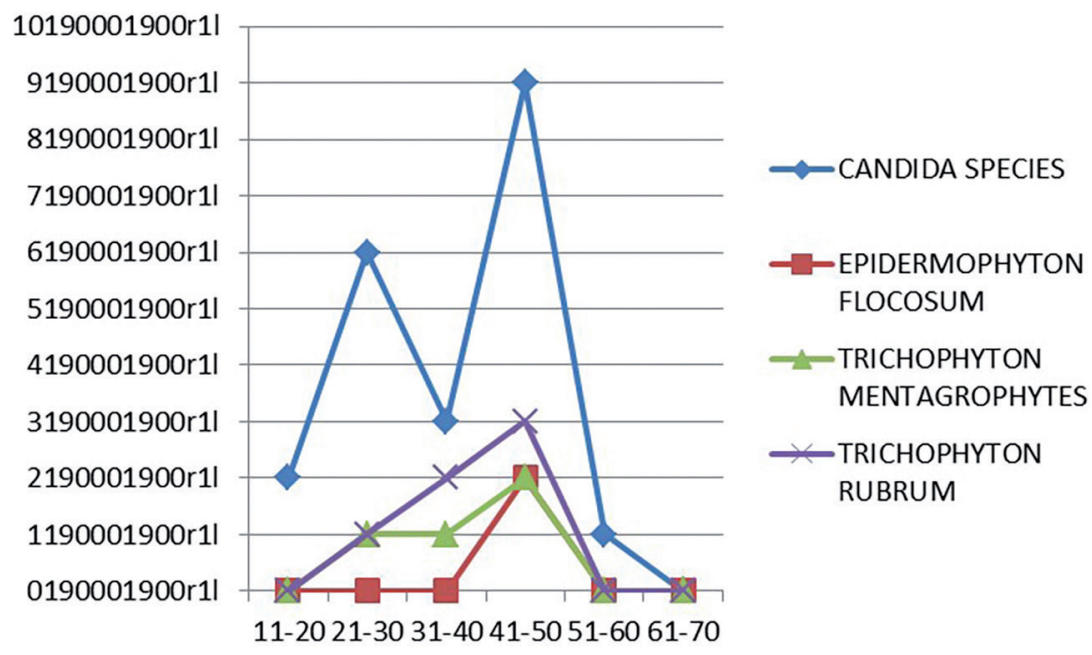

Figure 1. Distribution of fungal isolates by age of subjects.

Table 4 shows the distribution of lesion types on the subjects. Disto-lateral subungual onychomycosis (DLSO) $51(50.5 \%)$ were the most common

clinical type of nail lesions followed by Total dystrophic onychomycosis (TDO) 26 (25.7\%). Most of the isolates $14(42.4 \%)$ were recovered from TDO. 
Table 3. Distribution of fungal pathogens by body sites of subjects

\begin{tabular}{lcccc}
\hline Fungal isolates & Fingernails, No (\%) & Toenails, No (\%) & Finger \& Toe nails, No (\%) & Total, No (\%) \\
\hline Dermatophytes & & & & \\
$\quad$ T. rubrum & $2(33.3)$ & $4(66.7)$ & $0(0.0)$ & $6(18.2)$ \\
$\begin{array}{l}\text { T. mentagrophyte } \\
\text { E. flocosum }\end{array}$ & $0(0.0)$ & $3(75)$ & $1(25)$ & $4(12.1)$ \\
$\begin{array}{l}\text { Yeasts } \\
\quad \text { Candida species }\end{array}$ & $0(0.0)$ & $1(50)$ & $1(50)$ & $2(6.2)$ \\
\hline Total & $13(61.9)$ & $6(28.5)$ & $2(9.5)$ & $21(63.6)$ \\
\hline
\end{tabular}

Table 4. Distribution of fungal nail infections by subtypes of lesion on subjects

\begin{tabular}{lcc}
\hline Type of lesion & No (\%) with suggestive lesion & No. (\%) positive \\
\hline Disto- Lateral subungual onychomycosis & $51(50.5)$ & $12(36.4)$ \\
Proximal subungual onychomycosis & $21(20.8)$ & $6(18.2)$ \\
Superficial white onychomycosis & $3(3.0)$ & $1(3.0)$ \\
Total dystrophic onychomycosis & $26(25.7)$ & $14(42.4)$ \\
\hline Total & $101(100.0)$ & $33(32.7)$ \\
\hline
\end{tabular}

Onychomycosis appears to be a variable entity presenting in different forms in different part of the world with each country and region having its own characteristic presentation [17]. The prevalence of fungal nail infection in this study was $32.7 \%$. This is higher than the $6.5 \%$ prevalence reported in Canada by Gupta et al. [18] but lower than the $74.5 \%$ reported in India by Golia et al. [19] This picture shows that the prevalence rates for different countries and regions are variable.

Higher isolation rates were noted among males 23 (69.7) than females $10(30.3 \%)$. This was in agreement with previous studies in India, Pakistan and Kuwait [20,21]. Also, Gupta et al [18] had stated that men were up to three times more likely to have onychomycosis than women, though the reasons for this gender difference were not clear [14].

In this study subjects aged 21-50 years had higher rates of infection, which peaked at age 4150 years. However, Gupta et al [18] stated that the most prevalent predisposing risk factor for developing onychomycosis was advanced age between 60-79 years. In our study infection rates peaked between the 4th and 5 th decade of life. This may be due to the fact that fewer subjects in the 6 th and 7 th decade of life were enrolled in the study. The study was carried out in Calabar, which is an urban city. In our country most elderly people retire to the rural areas most times their village of origin.
Trichophyton rubrum has been reported in several studies as the most prevalent aetiologic agent in onychomycosis $[4,22]$ but in this study, Candida species $21(63.6 \%)$ was the most common isolate encountered. Although the reason for this was not investigated, it may be due to the high rates of other immunosuppressive conditions such as HIVIAIDS in our locality [23]. On the other hand, the dermatophytes including, Trichophyton rubrum were responsible for 12 (36.4\%). This shows that, in our locality the yeasts are a source of concern in onychomycosis aside the typical dermatophytes.

Total dystrophic onychomycosis 14 (42.4\%) was the most common presenting pattern of infection among our subjects. This differs from the studies of de Berker [3] Gupta and Ricci [2] with reports of DLSO as the most prevalent clinical types of onychomycosis. Total dystrophic onychomycosis (TDO) occurs more in immunodeficient patients, such as those with HIVIAIDS and chronic mucocutaneous candidiasis [3,13]. Although the level of immunodeficiency was not tested among our subjects, TDO may have been more prevalent because of the high rates of HIV infection in our locality [23].

Superficial White Onychomycosis (SWO) is always attributed to zoophilic transmission [22]. Only a case of SWO was seen in this study. This may be due to the fact that keeping animals which may act as vehicles of transmission as pets are uncommon in this part of the world. 


\section{CONCLUSION}

Onychomycosis affected more adults than adolescents of both sexes in our locality. Candida species are increasingly becoming prevalent etiologic agents of these infections, and their importance should not be overlooked in the management of patients. This study has proved that onychomycosis which is usually viewed as a cosmetic problem is an infection that requires medical attention. There is need to develop rapid diagnostic tests for onychomycosis to reduce the practice of empirical treatment.

Acknowledgement: This study was presented at the Meeting of American Society of Microbiology, 2015.

Declaration of Conflicting Interests: No conflict of interest of any author exists.

Financial Disclosure: The authors declared no financial support.

\section{REFERENCES}

1. Reiss E, Shadomy HJ, Lyod GM. Dermatophytosis and dermatomycoses (Superficial cutaneous mycoses): In: Fundamental medical mycology 2012; 1st ed. John Wiley \& Sons, Inc. Pp. 525-563.

2. Gupta AK, Ricci MJ. Diagnosing onychomycosis. Dermatol Clin 2006; 24(3): 365-9.

3. De Berker D. Clinical practice. Fungal nail disease. N Engl J Med 2009;360:2108-2116.

4. Havlickova A, Czaika VA, Friedrich M. Epidemiological trends in skin mycoses worldwide. Mycoses. 2008;51S4:2-15.

5. Grover C, Khurana A. Onychomycosis: newer insights in pathogenesis and diagnosis. Indian J Dermatol Venereol Leprol 2012;78:263-270.

6. Tosti A. Onychomycosis, Medscape, Apr 2012.

7. Gupta AK, Paquet M, Simpson FC. Therapies for the treatment of onychomycosis. Clin Dermatol 2013;31:544-554.

8. Friedlander SF, Chan YC, Chan YH, Eichenfield LF. Onychomycosis does not always require systemic treatment for cure: a trial using topical therapy. Pediatr Dermatol 2013;30:316322.
9. Ghannoum MA, Hajjeh RA, Scher R, et al. A large-scale North American study of fungal isolates from nails: the frequency of onychomycosis, fungal distribution, and antifungal susceptibility patterns. J Am Acad Dermatol 2000;43:641-648

10. Faergemann J, Correia O, Nowicki R, Ro BI. Genetic predisposition - understanding underlying mechanisms of onychomycosis. J Eur Acad Dermatol Venerol 2005;19:17-19.

11. Walid MS. A Simple and Affordable Technique for Treating Fungal Nail Infection: Case Report. WebmedCentral DERMATOLOGY 2012;3:WMC003594

12. Faergemann J, Baran R: Epidemiology, clinical presentation and diagnosis of onychomycosis. Br J Dermatol; 2003; 149 Suppl. 65:1-4.

13. Elewski BE. Clinical pearl: diagnosis of onychomycosis. J Am Acad Dermatol. 1995;32:500-501.

14. Carney C, Tosti A, Daniel R, et al. A new classification system for grading the severity of onychomycosis: Onychomycosis Severity Index. Arch Dermatol 2011;147:1277-1282.

15. Singh G, Haneef NS, Uday A. Nail changes and disorders among the elderly. Indian J Dermatol Venereol Leprol 2005;71:386-392.

16. Tosti A, Piraccini BM, Lorenzi S, lorizzo M. Treatment of non dermatophyte mold and Candida onychomycosis. Dermatol Clin 2003;21:491-497.

17. Harvey A. Fungal Nails (Onychomycosis, Tinea Unguium) Causes, Symptoms, Signs and Treatment on MedicineNet. com 2010; http://www.medicinenet.com/fungal_nails/article

18. Gupta AK, Jain HC, Lynde CW, et al. Prevalence and epidemiology of onychomycosis in patients visiting physicians' offices: a multicenter Canadian survey of 15,000 patients. $J$ Am Acad Dermatol 2000;43:244-248.

19. Golia S, Hittinahalli V, Vasudha C. L, et al. A study on the mycological profile of onychomycosis. Journal of Evolution of Medical and Dental Sciences 2012;1:1247-1255.

20. Malik NA, Raza N and Nasiruddin. Nondermatophyte moulds and yeasts as causative agents in onychomycosis. J Pakist Assoc Dermatol 2009;19:74-78.

21. Yehia MA, El-Ammawi TS, Al-Mazidi KM, et al. The Spectrum of fungal infections with a special reference of dermatophytoses in the capital area of Kuwait during. 2000-2005: A retrospective analysis. Mycopathol 2010;169:241-246.

22. Ghannoum M, Isham N. Fungal Nail Infections (Onychomycosis): A Never-Ending Story? PLoS Pathog 2014;10:e1004105.

23. Federal Ministry of Health (2005). Technical report: National $\mathrm{HIV/syphilis} \mathrm{sero-prevalance} \mathrm{sentinels} \mathrm{survey} \mathrm{among} \mathrm{preg-}$ nant women attending ante-natal clinics in Nigeria. Lagos: FMH Press. 